\title{
In vitro ovicidal and larvicidal activity of condensed tannins on gastrointestinal nematode infestations in sheep (Ovis aries)
}

\section{Atividade ovicida e larvicida in vitro de taninos condensados em nematódeos gastrintestinais de ovinos (Ovis aries)}

\author{
Eidi Yoshihara ${ }^{1 *}$; Alessandro Pelegrine Minho²; Sérgio Tosi Cardim³; Victor \\ Bittencourt Dutra Tabacow ${ }^{3}$; Milton Hissashi Yamamura ${ }^{4}$
}

\begin{abstract}
Infestations of gastrointestinal parasitic nematodes in sheep result in significant costs to farmers. These infestations are controlled using synthetic anthelmintic treatments, which can result in the development of anthelmintic resistance in nematodes. The use of plants rich in condensed tannins (CTs) is a promising alternative for controlling infestations of harmful parasites in sheep, and could allow reduction of the chemical products used. This study investigated the in vitro effect of CTs from Acacia mearnsii extract (AE) on egg hatching and motility of third-stage larvae. Egg-hatching rate was measured after incubation with extracts for $48 \mathrm{~h}$ at $27^{\circ} \mathrm{C}$. The egg hatch test was performed with dilutions of $0.09,0.19,0.39$, $0.78,1.56,3.12,6.25,12.5,25,50$, and $100 \mathrm{mg} \mathrm{mL}^{-1}$. Distilled water was used as the negative control. The corresponding egg hatching inhibition percentages were 22.3, 32.3, 39.2, 49.1, 56.7, 59.0, 62.3, $77.3,92.7,98.3$, and $100 \%$. The concentration required to inhibit egg hatching in $50 \%$ of eggs $\left(\mathrm{LC}_{50}\right)$ was $2.85 \mathrm{mg} \mathrm{mL}^{-1}$. The inhibition achieved with the negative control was $7.06 \%$. A larval migration inhibition test was carried out after incubation with the extracts for $48 \mathrm{~h}$ at $27{ }^{\circ} \mathrm{C}$, with $\mathrm{AE}$ and distilled water used in dilutions of $3.12,6.25,12.5,25,50$, and $100 \mathrm{mg} \mathrm{mL}^{-1}$. The corresponding percentages of migration inhibition were $16.5,37.0,56.3,79.4,91.8$, and $97.1 \%$. The concentration required to inhibit migration of $50 \%$ of larvae $\left(\mathrm{LC}_{50}\right)$ was $12.45 \mathrm{mg} \mathrm{mL}^{-1}$. The inhibition achieved with the negative control was $8.53 \%$. The in vitro ovicidal and larvicidal activity of CTs from AE indicate the anthelmintic effect of AE, suggesting the potential of $\mathrm{CT}$ extracts to be used as alternatives for controlling gastrointestinal nematode infestations in small ruminants.
\end{abstract}

Key words: In vitro test, helminthes, tannins, phytotherapy, small ruminants

\section{Resumo}

O parasitismo gastrintestinal em ovinos acarreta inúmeros prejuízos aos produtores rurais. O controle é realizado basicamente através da administração de anti-helmínticos sintéticos o que estimula a seleção de parasitas resistentes. O uso de plantas ricas em taninos condensados (TC) apresenta-se como uma alternativa promissora no controle de helmintos em ovinos, reduzindo o uso de produtos químicos. Esse estudo avaliou o efeito in vitro dos TC provenientes da acácia (Acacia mearnsii) sobre a eclosão de ovos e a motilidade de larvas de terceiro estágio de nematódeos gastrintestinais de ovinos. A taxa

\footnotetext{
${ }^{1}$ Pesquisador, Agência Paulista de Tecnologia dos Agronegócios - Polo Alta Sorocabana, APTA, Presidente Prudente, SP, Brasil. E-mail: eidi@apta.sp.gov.br

${ }^{2}$ Pesquisador, Empresa Brasileira de Pesquisa Agropecuária - Pecuária Sul, EMBRAPA, Bagé, RS, Brasil. E-mail: alessandro. minho@embrapa.br

${ }^{3}$ Discentes, Universidade Estadual de Londrina, UEL, Londrina, PR, Brasil. E-mail: stcardim@hotmail.com; victor.tabacow@ gmail.com

${ }^{4}$ Prof. Dr., Universidade Estadual de Londrina, Londrina, PR, Brasil. E-mail: yamamura@uel.br

* Author for correspondence
} 
de eclosão foi avaliada após incubação com o extrato por um período de $48 \mathrm{~h}$ a $27{ }^{\circ} \mathrm{C}$. A eclodibilidade foi avaliada nas concentrações de 0,$09 ; 0,19 ; 0,39 ; 0,78 ; 1,56 ; 3,12 ; 6,25 ; 12,5 ; 25 ; 50$ e $100 \mathrm{mg} \mathrm{mL}^{-1}$. No controle negativo utilizou-se água destilada. As inibições das eclosões foram 22,$3 ; 32,3 ; 39,3 ; 49,1$; 56,$7 ; 59 ; 62,3 ; 77,3 ; 92,7 ; 98,3$ e $100 \%$, respectivamente. Para a inibição de $50 \%$ da eclosão de ovos $\left(\mathrm{CL}_{50}\right)$ o valor foi de $2,85 \mathrm{mg} \mathrm{mL}^{-1}$. No controle negativo a inibição foi de 7,1\%. A inibição da migração larval foi avaliada após incubação com o extrato por um período de $3 \mathrm{~h}$ a $27{ }^{\circ} \mathrm{C}$, nas concentrações de 3,$12 ; 6,25 ; 12,5 ; 25 ; 50$ e $100 \mathrm{mg} \mathrm{mL}^{-1}$. As porcentagens de inibição foram: 16,5; 37; 56,3; 79,4; 91,8 e $97,1 \%$ respectivamente. Para a inibição de $50 \%$ da migração larval $\left(\mathrm{CL}_{50}\right)$, o valor da concentração foi de $12,45 \mathrm{mg} \mathrm{mL}^{-1}$. No controle negativo a inibição foi de $8,5 \%$. A ação ovicida e larvicida in vitro do tanino condensado do extrato de Acacia mearnsii encontrada no presente trabalho indica uma ação anti-helmíntica, apresentando potencial para sua aplicação no controle alternativo de nematódeos gastrintestinais de pequenos ruminantes.

Palavras-chave: Teste in vitro, helmintos gastrintestinais, taninos, fitoterapia, pequenos ruminantes

\section{Introduction}

Gastrointestinal nematodes are said to be the main limiting factor in sheep production, causing the greatest economic losses for producers worldwide (ADEMOLA; ELLOF, 2010). Currently, helminths are controlled using anthelmintic drugs. However, the global increase in anthelminthic resistance, emergence of resistant isolates (FORTES; MOLENTO, 2013), worrying presence of residues in food, and environmental pollution (ATHANASIADOU; HOUDIJK; KYRIAZAKIS, 2008) have all been an incentive for further research into alternative methods to control helminths (CEZAR; CATTO; BIANCHIN, 2008).

New alternative methods of controlling gastrointestinal parasites have been researched, some of which involve tanniniferous plants, which may be a promising option to reduce the severity of nematode infections in small ruminants and the use of anthelminthic drugs. The incubation of eggs and larvae with plant extracts rich in tannins has produced positive results with regard to egg eclosion, and the mobility and exsheathment of larvae (BARRAU et al., 2005; BRUNET et al., 2007; MOLAN; FARAJ, 2010; OLIVEIRA et al., 2011a). A decrease in the parasitic load and number of eggs eliminated has also been described in sheep and goats when using tanniniferous plants (LANGE et al., 2006; HECKENDORN et al., 2007; MINHO et al., 2010; PARRA et al., 2011).
Tannins are secondary plant metabolites, classified into hydrolysable tannins (HT) and condensed tannins (CTs). CTs are most commonly found in forest legumes, trees, and bushes (MIN; HART, 2003). Various species of plants and extracts have been studied to determine if they possess anthelminthic properties, particularly with regard to the action of CTs (OLIVEIRA et al., 2011a; SHALDERS et al., 2013), in an attempt to prove the direct and indirect effects of CTs on gastrointestinal nematodes in sheep. The in vitro anthelminthic activity of CTs can be assessed at different stages of nematode development, with the effects recorded being reduction in eclosion, larval exsheathment, and motility. The main advantages of in vitro tests are their low cost and the fact that data can be rapidly collected (GITHIORI; ATHANASIADOU; THAMSBORG, 2006). The exact mechanism of action of tannins is still unknown and may differ according to parasite, stage of development, and biochemical characteristics of the plant (HOSTE et al., 2006). This study aimed to assess the in vitro effects of CTs from the acacia (Acacia mearnsii) plant on the eggs and third-stage larvae $\left(\mathrm{L}_{3}\right)$ of gastrointestinal sheep nematodes.

\section{Materials and Methods}

\section{Source of CTS}

The source of the CTs was a commercial extract of $A$. mearnsii bark (universal use acacia extract, 
Seta $\operatorname{Sun}^{\circledR}$. Seta S.A.), containing $72.5 \%$ tannins. This extract contained $15 \% \mathrm{CTs}$ as per the $\mathrm{HCl}-$ butanol method described by Porter, Hrstich and Chan (1986).

\section{Animals}

Two naturally infected sheep, from the region of Londrina, PR, Brazil, were kept in a stable in the Isolation Unit of the Veterinary Hospital at the Londrina State University and fed a tanninfree diet. Isolation and identification of the fecal matter revealed the presence of four genera of nematodes frequently found in naturally infected animals in the Londrina region. The genera found were Haemonchus (84\%), Trichostrongylus (13\%), Oesophagostomum (2\%), and Cooperia (1\%). These animals were used as the source of helminth larvae.

\section{Isolation of eggs and third-stage larvae}

The feces were collected directly from the rectum of the animals, and the eggs were isolated and a fecal culture was prepared to obtain thirdstage larvae $\left(\mathrm{L}_{3}\right)$. The eggs were recovered according to the methodology described by Coles et al. (1992) and adapted by Bizimenyera et al. (2006). The feces were homogenized in distilled water and filtered using a series of sieves, with the eggs being removed using a $25 \mathrm{~mm}$ sieve, washed with distilled water, and centrifuged at 1,100 x $g$ for $5 \mathrm{~min}$ in $50-\mathrm{mL}$ tubes containing water. The supernatant was discarded and saturated saline solution was added to resuspend the sediment. After another centrifugation using the same conditions as described above, the supernatant was washed in a $25 \mathrm{~mm}$ sieve. The collected eggs were stored in a sedimentation beaker for $2 \mathrm{~h}$. After syphoning, the eggs were counted in five aliquots of $100 \mathrm{~mL}$.

\section{Egg eclodibility assay (EEA)}

The test was based on the method described by Von Samson-Himmelstjerna, Coles, and Jackson
(2009). Dilutions of the A. mearnsii extract (EA) were prepared using distilled water. The final concentrations of the extract were: $0.09,0.19$, $0.39,0.78,1.56,3.12,6.25,12.5,25,50$, and 100 $\mathrm{mg} \mathrm{mL} \mathrm{mL}^{-1}$. Subsequently, a $100-\mu \mathrm{L}$ suspension of the eggs, containing approximately 150 eggs, was incubated in 24-well cell culture plates for 48 hours at $27{ }^{\circ} \mathrm{C}$ with $400 \mu \mathrm{L}$ of each dilution. The test was carried out using two controls: the negative control comprised distilled water, and the positive comprised albendazole sulfoxide (50 $\mu \mathrm{g} \mathrm{mL}$, Ricofarm $10^{\circledR}$, Biofarm). The test was carried out with six repetitions for each concentration tested. After the incubation period, the ecloded eggs and larvae were quantified to calculate the percentage inhibition of larval eclodibility. Reading was performed using an inverted microscope Motic AE 31 with a $10 x$ resolution.

\section{Larval migration inhibition assay (LMI)}

The LMI assay was carried out according to the methodology described by Rabel, McGregor, and Douch (1994). Larvae were obtained from the fecal culture of naturally infected sheep. Approximately $150 \mathrm{~L}_{3}$ were incubated at $27{ }^{\circ} \mathrm{C}$ in Eppendorf tubes containing $1 \mathrm{~mL}$ of the plant extract diluted in distilled water to concentrations of: $3.12,6.25,12.5,25,50$, and $100 \mathrm{mg} \mathrm{mL}^{-1}$. The test was carried out using two controls: the negative comprising distilled water and the positive comprising levamisole phosphate (40 $\mu \mathrm{g} \mathrm{mL}^{-1}$, Ripercol ${ }^{\circledR}$, Fort Dodge). After $3 \mathrm{~h}$ of incubation, the tubes were centrifuged at $1,100 \times \mathrm{x}$ for $2 \mathrm{~min}$, and the supernatant was discarded leaving $200 \mu \mathrm{L}$. A 1,800- $\mu \mathrm{L}$ aliquot of each AE dilution was added to each of the 24 wells on the cell culture plate, with this test being carried out in sextuplicate. Next, a 22- $\mu \mathrm{m}$ mesh filter was added to the wells and 200 $\mu \mathrm{L}$ of the larval suspension was added to the top of the filter in the respective concentrations tested. The plate was covered and placed in a B.O.D. incubator chamber for $2 \mathrm{~h}$ at $27^{\circ} \mathrm{C}$. The number of larvae that remained or migrated was counted using an inverted microscope Motic AE 31 at a 10x resolution. 


\section{Statistical analysis}

In the EEA and LMI assays, the effectiveness of both treatments was determined based on the percentage of eclosion or migration, according to the following equation: Inhibition $(\%)=100\left(\mathrm{~N}_{\text {test }} /\right.$ $\mathrm{N}_{\text {total }}$, where $\mathrm{N}_{\text {test }}$ corresponds to the number of nonecloded eggs, EEA, or number of larvae that did not migrate in the LMI, and $\mathrm{N}_{\text {total }}$ corresponds to the number of eggs $+\mathrm{L}_{1}$ in the EEA test or the number of migrated larvae + remaining larvae in the LMI test.

The $50 \%$ lethal concentration $\left(\mathrm{LC}_{50}\right)$, which is the concentration that can effectively inhibit 50\% of eclosion or migration, was determined using the dose-response curve, with a confidence interval of $95 \%$, using the program GraphPad Prism for Windows, version 5.0.

\section{Ethics Committee}

This article was approved by the Ethics Committee of Animal Research at Londrina
State University, recorded in the CEEA with the no. $87 / 09$, and was carried out under the ethical principles stated by the Brazilian College of Animal Experimentation (COBEA).

\section{Results}

\section{Inhibition of egg eclosion}

The $\mathrm{LC}_{50}$ value for the inhibition of egg eclosion by AE was $2.85 \mathrm{mg} \mathrm{mL}^{-1}$ (95\% CI: $2.45-3.31 \mathrm{mg}$ $\left.\mathrm{mL}^{-1}\right)$. The positive control was $100 \%$ effective in inhibiting eclosion, and with the negative control, the mean inhibition was $7.1 \%$. The percentage eclosion inhibition of gastrointestinal nematode eggs using concentrations between 0.09 and $100 \mathrm{mg}$ $\mathrm{mL}^{-1}$ of AE varied between 22.3 and $100 \%$ inhibition, respectively (Figure 1). With concentrations below $0.09 \mathrm{mg} \mathrm{mL}^{-1}$, the degree of inhibition was similar to that with the negative control. There was $100 \%$ inhibition with the positive control, albendazole sulfoxide (50 $\mu \mathrm{g} \mathrm{mL}^{-1}$, Ricofarm $10^{\circledR}$, Biofarm).

Figure 1. Effect of the Acacia mearnsii extract on the egg hatchability of gastrointestinal nematode of sheep

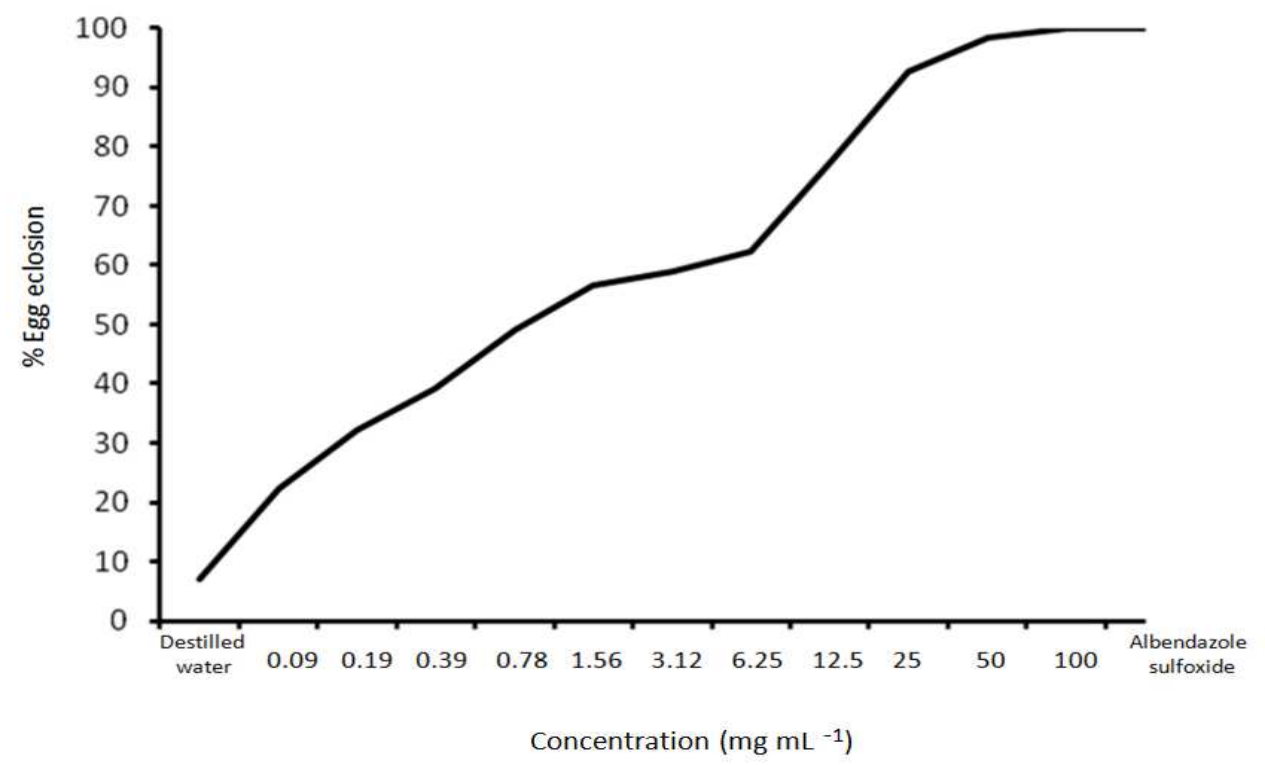

Source: Elaboration of the authors. 


\section{Inhibition of larval migration}

The $\mathrm{LC}_{50}$ value of $\mathrm{AE}$ for the inhibition of larval migration was $12.45 \mathrm{mg} \mathrm{mL}^{-1}(95 \% \mathrm{CI}: 11.49$ $\left.13.47 \mathrm{mg} \mathrm{mL}^{-1}\right)$. The positive control was $100 \%$ effective in inhibiting larval migration and the negative control had a mean inhibition of $8.5 \%$.
The percentage of larval migration inhibition using concentrations of AE between 3.12 and $100 \mathrm{mg}$ $\mathrm{mL}^{-1}$ varied between 16.5 and $97.1 \%$ inhibition, respectively (Figure 2). There was $100 \%$ inhibition with the positive control, levamisole phosphate (40 $\mu \mathrm{g} \mathrm{mL}{ }^{-1}$, Ripercol ${ }^{\circledR}$, Fort Dodge).

Figure2. Effect of the Acacia mearnsii extract on the inhibition of larval migration (infective larvae) of gastrointestinal nematodes of sheep.

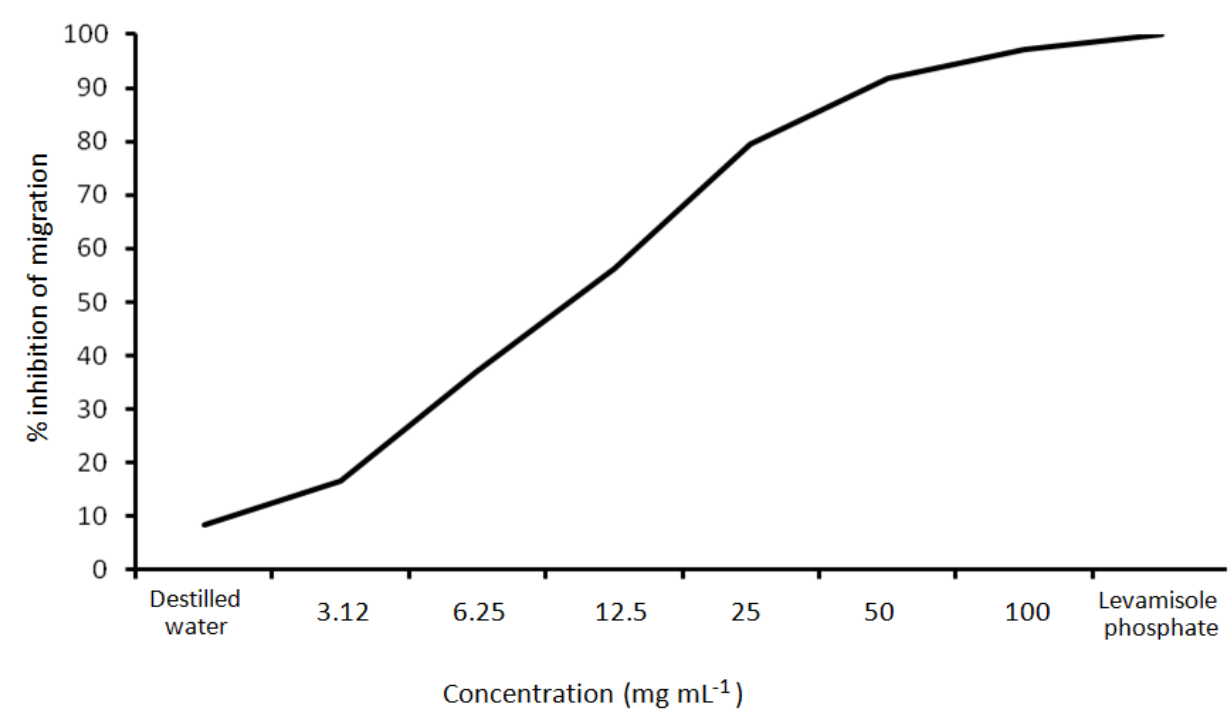

Source: Elaboration of the authors.

\section{Discussion}

In the in vitro tests carried out in this study, the inhibitory action of AE was demonstrated by the inhibition of egg eclosion and of the larval migration of gastrointestinal nematodes in naturally infected sheep. Two hypotheses, based on the direct and indirect effects of tannins, have been used to explain this anthelminthic action. However, the exact mechanism of action of these metabolites is still not fully understood and may differ according to the parasite, stage of development, and possibly, on the biochemical characteristics of the plants studied (HOSTE et al., 2006). Both in vitro and in vivo tests were carried out to assess the anthelminthic action of AE. The efficiency of AE was tested in vivo by
Cenci et al. (2007) and Max (2010) using naturally infected sheep, and showed a drop in the eggs per gram of faeces (EPG) count and a decrease in parasitic load. Minho et al. (2008) assessed the in vitro inhibitory effect of $\mathrm{AE}$ on the feeding of the stage one larvae $\left(\mathrm{L}_{1}\right)$ of Haemonchus contortus, Trichostrongylus colubriformis, and Teladorsagia circumcincta. According to the authors, AE inhibited $\mathrm{L}_{1}$ feeding. In another study, Minho et al. (2010) observed a decrease in the elimination of eggs and parasitic load of T. colubriformis in experimentally infected sheep. This study showed the inhibitory effect of CTs present in the AE, consistent with the results found by other authors, when they assessed the anthelminthic action of the $\mathrm{AE}$ as a source of CTs. 
Several authors have assessed the anthelminthic effect of extracts of different tannin-containing plants using in vitro techniques. The effects of the extracts of six tannin-rich tropical plants were tested by Oliveira et al. (2011b), who showed the inhibition of larval development in $H$. contortus indicating anthelminthic activity in in vitro tests. Son-de Fernex et al. (2012) assessed the anthelminthic activity of five plants containing CTs, showing that there was an inhibitory effect on the motility and exsheathment of infected $H$. contortus larvae.

The concentration required to inhibit 100\% eclosion and the $\mathrm{LC}_{50}\left(100 \mathrm{mg} \mathrm{mL}^{-1}\right.$ and 2.85 $\mathrm{mg} \mathrm{mL}^{-1}$, respectively) in this study were higher than the values stated in previous studies, where Molan, Waghorn, and McNabb (2002) reported total inhibition of egg eclosion in T. colubriformis at concentrations between 200 and $500 \mu \mathrm{g} \mathrm{mL}-1$, depending on the plant analyzed. In another study, Molan et al. (2003) found 100\% inhibition of egg eclosion in T. colubriformis at a concentration of $1000 \mu \mathrm{g} \mathrm{mL} \mathrm{mL}^{-1}$. Bizimenyera et al. (2006) tested extracts of different parts of Peltophorum africanum, and found that a concentration of $25 \mu \mathrm{g} \mathrm{mL}^{-1}$ of all extracts caused $100 \%$ inhibition of egg eclosion in T. colubriformis, with $\mathrm{LC}_{50}$ values of $0.619,0.383$, and $0.280 \mathrm{mg} \mathrm{mL}^{-1}$ for leaf, bark, and root extracts, respectively. Maciel et al. (2006) also showed $100 \%$ inhibition of egg eclosion in $H$. contortus with a $25-\mu \mathrm{g} \mathrm{mL}^{-1}$ concentration of the ethanolic extract of leaves, whereas the hexanic extract, at a concentration of $50 \mu \mathrm{g} \mathrm{mL} \mathrm{mL}^{-1}$, inhibited eclosion by only $16.92 \%$. The $\mathrm{LC}_{50}$ values were 35.8 and 2.2 $\mu \mathrm{g} \mathrm{mL} \mathrm{m}^{-1}$ for the hexanic and ethanolic leaf extracts, respectively. In the same study, extracts of seeds were tested; there was total inhibition with the ethanolic extract at a concentration of $3.12 \mu \mathrm{g} \mathrm{mL}^{-1}$, whereas the chloroformic extract, at a concentration of 50 $\mu \mathrm{g} \mathrm{mL} \mathrm{m}^{-1}$, showed an inhibition of $92.39 \%$. The $\mathrm{LC}_{50}$ values were 0.36 and $7.26 \mu \mathrm{g} \mathrm{mL}^{-1}$ for the ethanolic and chloroformic extracts, respectively. Oliveira et al. (2011a) tested Myracrodruon urundeuva extracts on $H$. contortus larvae, and found that there was
$100 \%$ inhibition at a concentration of $2.5 \mu \mathrm{g} \mathrm{mL}^{-1}$ of the leaf extract and $83.56 \%$ inhibition at $5 \mu \mathrm{g} \mathrm{mL}-1$ of the stem extract.

The values of $97.1 \%$ inhibition of larval migration with the $100 \mathrm{mg} \mathrm{mL}^{-1}$ concentration and an $\mathrm{LC}_{50}$ of $12.85 \mathrm{mg} \mathrm{mL}^{-1}$ shown in this study are higher than those found in the literature. Alonso-Díaz et al. (2008) assessed the action of four tannin-rich plants in stage three $H$. contortus larvae and found different degrees of inhibition, varying between 49.1 and $63.8 \%$, when they used an extract at a concentration of 1,200 $\mu \mathrm{g} \mathrm{mL}^{-1}$. In another study, Alonso-Díaz et al. (2011) found migration inhibitions of 48.5 and 20.9\% for Havardia albicans and Acacia gaumeri, respectively, at a concentration of $1,200 \mu \mathrm{g} \mathrm{mL}$. Furthermore, with a concentration of $1,200 \mu \mathrm{g} \mathrm{mL}$ 1, Manolaraki et al. (2010) tested seven plants and found inhibition of migration to vary between 38.9 and $79.1 \%$.

The concentrations that inhibited $100 \%$ of egg eclosion varied between 3.12 and $1000 \mu \mathrm{g} \mathrm{mL}^{-1}$ in the literature. With regard to the inhibition of larval migration, there are studies that show different degrees of inhibition at a concentration of $1,200 \mu \mathrm{g}$ $\mathrm{mL}^{-1}$, varying between 20.9 and $79.1 \%$. The values stated for a $50 \%$ inhibition of egg eclosion $\left(\mathrm{CL}_{50}\right)$ in studies carried out by different authors vary between $0.36 \mu \mathrm{g} \mathrm{mL}^{-1}$ and $7.26 \mathrm{mg} \mathrm{mL}^{-1}$. The values found in this study are higher than those found in previous studies on CT sources. The differences in the values found in this study may be due to the source of CT, extraction methods, and the strains of parasites assessed.

In the long term, the main contribution that this compound could offer would be to decrease the number of anthelminthic applications required and reduce the contamination of pastures, increasing the time between chemical treatments. This would decrease selection pressure on the parasite population, thereby minimizing the risk or delaying the development of isolates resistant to the drugs used. 


\section{Conclusions}

The results obtained in this study reveal the in vitro anthelminthic action of the $\mathrm{AE}$ on egg eclosion and the migration of stage-three larvae of gastrointestinal nematodes of naturally infected sheep.

Further studies are necessary to define some aspects associated with the extraction methods and therapeutic dose so that that there is more consistency in production, in order to make the use of these compounds viable in the alternative control of nematodes, either together with chemical products, on properties with anthelminthic resistance, or for use on properties that adopt an organic production system.

\section{References}

ADEMOLA, I. O.; ELOFF, J. N. In vitro anthelmintic activity of Combretum molle (R. Br. ex G. Don) (Cunbretaceae) against Haemonchus contortus ova and larvae. Veterinary Parasitology, Amsterdam, v. 169, n. 1-2, p. 198-203, 2010.

ALONSO-DÍAZ, M. A.; TORRES-ACOSTA, J. F. J.; SANDOVAL-CASTRO, C. A.; AGUILARCABALlERO, A. J.; HOSTE, H. In vitro larval migration and kinetics of exsheathment of Haemonchus contortus larvae exposed to four tropical tanniniferous plant extracts. Veterinary Parasitology, Amsterdam, v. 153, n. 3-4, p. 313-319, 2008.

ALONSO-DÍAZ, M. A.; TORRES-ACOSTA, J. F. J.; SANDOVAL-CASTRO, C. A.; HOSTE, H. Comparing the sensitivity of two in vitro assays to evaluate the anthelmintic activity of tropical tannin rich plant extracts against Haemonchus contortus. Veterinary Parasitology, Amsterdam, v. 181, n. 2-4, p. 360-364, 2011.

ATHANASIADOU, S.; HOUDIJK, J.; KYRIAZAKIS, I. Exploiting synergisms and interactions in the nutritional approaches to parasite control in sheep production systems. Small Ruminant Research, Amsterdam, v. 76, n. 1, p. 2-11, 2008.

BARRAU, E.; FABRE, N.; FOURASTE, I.; HOSTE, H. Effect of bioactive compounds from Sainfoin (Onobrychis viciifolia Scop.) on the in vitro larval migration of Haemonchus contortus: role of tannins and flavonol glycosides. Parasitology, Cambrigde, v. 13, n. 4, p. 531-538, 2005.
BIZIMENYERA, E. S.; GITHIORI, J. B.; ELOFF, J. N.; SWAN, G. E. In vitro activity of Peltophorum africanum Sond. (Fabaceae) extracts on the egg hatching and larval development of the parasitic nematode Trichostrongylus colubriformis. Veterinary Parasitology, Amsterdam, v. 142, n. 3-4, p. 336-343, 2006.

BRUNET, S.; AUFRERE, J.; BABILI, F.; FOURASTE, I.; HOSTE, H. The kinetics of exsheathment of infective nematode larvae is disturbed in presence of a tanninrich plant extract (sainfoin) both in vitro and in vivo. Parasitology, Cambridge, v. 134, n. 9, p. 1253-1262, 2007.

CENCI, F. B.; LOUVANDINI, H.; MCMANUS, C. M.; DELL'PORTO, A.; COSTA, D. M.; ARAÚJO, S. C.; MINHO, A. P.; ABDALLA, A. L. Effects of condensed tannin from Acacia mearnsii on sheep infected naturally with gastrointestinal helminthes. Veterinary Parasitology, Amsterdam, v. 144, n. 1-2, p. 132-137, 2007.

CEZAR, A. S.; CATTO, J. B.; BIANCHIN, I. Controle alternativo de nematódeos gastrintestinais dos ruminantes: atualidade e perpectivas. Ciência Rural, Santa Maria, v. 38, n. 7, p. 2083-2091, 2008.

COLES, G. C.; BAUER, C.; BOTGSTEEDE, F. H. M.; GEERTS, S.; KLEI, T. R.; TAYLOR, M. A.; WALLER, P. J. World association for the advancement of veterinary parasitology (W.A.A.P.) methods for the detection of anthelmintic resistance in nematodes of veterinary importance. Veterinary Parasitology, Amsterdam, v. 44, n. 1-2, p. 35-44, 1992.

FORTES, F. S.; MOLENTO, M. B. Resistência antihelmíntica em nematoides gastrintestinais de pequenos ruminantes: avanços e limitações para seu diagnóstico. Pesquisa Veterinária Brasileira, Rio de Janeiro, v. 33, n. 12, p. 1391-1402, 2013.

GITHIORI, J. B.; ATHANASIADOU, S.; THAMSBORG, S. M. Use of plants in novel approaches for control of gastrointestinal helminths in livestock with emphasis on small ruminants. Veterinary Parasitology, Amsterdam, v. 139, n. 4, p. 308-320, 2006.

HECKENDORN, F.; HÄRING, D. A.; MAURER, V.; SENN, M.; HERTZBERG, H. Individual administration of three tanniferous forage plants to lambs artificially infected with Haemonchus contortus and Cooperia curticei. Veterinary Parasitology, Amsterdam, v. 146, n. 1-2, p. 123-134, 2007.

HOSTE, H.; JACKSON, F.; ATHANASIADOU, S.; THAMSBORG, S. M.; HOSKIN, S. O. The effects of tannin-rich plants on parasitic nematodes in ruminants. Trends in Parasitology, Philadelphia, v. 22, n. 6, p. 253261, 2006. 
LANGE, K. C.; OLCOTT, D. D.; MILLER, J. E.; MOSJIDIS, J. A.; TERRILL, T. H.; BURKE, J. M.; KEARNEY, M. T. Effect of sericea lespedeza (Lespedeza cuneata) fed as hay, on natural and experimental Haemonchus contortus infections in lambs. Veterinary Parasitology, Amsterdam, v. 141, n. 3-4, p. 273-278, 2006.

MACIEL, M. V.; MORAIS, S. M.; BEVILAQUA, C. M. L.; CAMURÇA-VASCONCELOS, A. L. F.; COSTA, C. T. C.; CASTRO, C. M. S. Ovicidal and larvicidal activity of Melia Azedarach extracts on Haemonchus contortus. Veterinary Parasitology, Amsterdam, v. 140, n. 5, p. 98104, 2006.

MANOLARAKI, F.; SOTIRAKI, S.; STEFANAKIS, A.; SKAMPARDONIS, V.; HOSTE, M.; HPSTE, H. Anthelmintic activity of some Mediterranean browse plants against parasitic nematodes. Parasitology, Cambridge, v. 137, n. 4, p. 685-696, 2010.

MAX, R. A. Effect of repeated wattle tannin drench on worm burdens, fecal egg counts and egg hatchability naturally acquired nematode infections in sheep and goats. Veterinary Parasitology, Amsterdam, v. 169, n. 1-2, p. 138-143, 2010.

MIN, B. R.; HART, S. P. Tannin for suppression of internal parasites. Journal of Animal Science, Champaign, v. 81, p. 102-109, 2003. Supplement 2.

MINHO, A. P.; BUENO, I. C. S.; GENNARI, S. M.; JACKSON, F.; ABDALLA, A. L. In vitro effect of condensed tannin extract from Acacia (Acacia mearnsii) on gastrointestinal nematodes of sheep. Revista Brasileira de Parasitologia Veterinária, São Paulo, v. 17, p. 147151, 2008. Supplement 1.

MINHO, A. P.; FILIPPSEN, L. F.; AMARANTE, A. F. T.; ABDALLA, A. L. Efficacy of condensed tannin presents in acacia extract on the control of Trichostrongylus colubriformis in sheep. Ciência Rural, Santa Maria, v. 40, n. 6, p. 1360-1365, 2010.

MOLAN, A. L.; MEAAGHER, L. P.; SPENCER, P. A.; SIKAKUMARAN, S. Effect of flavan-3-ols on in vitro egg hatching, larval development and viability of infective larvae of Trichostrongylus colubriformis. International Journal for Parasitology, Oxford, v. 33, n. 14, p. 1691-1698, 2003.

MOLAN, A. L.; FARAJ, A. M. The effects of condensed tannins extracted from different plant species on egg hatching and larval development of Teladorsagia circumcincta (Nematoda: Trichostrongylidae). Folia Parasitologica, Ceské Budejovice, v. 57, n. 1, p. 62-68, 2010.

MOLAN, A. L.; WAGHORN, G. C.; McNABB, W. C.
Effect of condensed tannins on egg hatching and larval development of Trichostrongylus colubriformis in vitro. Veterinary Record, London, v. 150, n. 3, p. 65-69, 2002.

OLIVEIRA, L. M. B.; BEVILAQUA, C. M. L.; MACEDO, I. T. F.; MORAIS, S. M.; MACHADO, L. K. A.; CAMPELLO, C. C.; MESQUITA, M. A. Effects of Myracrodrum urundeuva extracts on egg hatching and larval exsheathment of Haemonchus contortus. Parasitology Research, Paris, v. 109, n. 3, p. 893-898, 2011b.

OLIVEIRA, L. M. B.; BEVILAQUA, C. M. L.; MACEDO, I. T. F.; MORAIS, S. M.; MONTEIRO, M. V. B.; CAMPELLO, C. C.; RIBEIRO, W. L. C.; BATISTA, E. K. F. Effects of six tropical plant extracts on larval exsheathment of Haemonchus contortus. Revista Brasileira de Parasitologia Veterinária, Jaboticabal, v. 20, n. 2, p. 155-160, 2011 a.

PARRA, C. L. C.; OLIVO, C. J.; FLORES, F. S.; AGNOLIN, C. A. P. C. C.; BOLZAN, A. M. S. Alteração da carga de endoparasitas em ovinos submetidos a diferentes níveis de folha de bananeira na alimentação. Revista Brasileira de Agroecologia, Cruz Alta, v. 6, n. 1, p. 111-116, 2011.

PORTER, L. J.; HRSTICH, L. N.; CHAN, B. G. The conversion of procyanidins and prodelphinidins to cyanidin and delphinidin. Phytochemistry, Kidlington, v. 25, n. 1 p. 223-230, 1986.

RABEL, B.; McGREGOR, R.; DOUCH, P. G. Improved bioassay for estimation of inhibitory effects of ovine gastrointestinal mucus and anthelmintics on nematode larval migration. International Journal for Parasitology, Oxford, v. 24, n. 5, p. 671-676, 1994.

SHALDERS, E.; ZANINI, S. F.; SOUSA, D. R.; CLIPES, R. C.; BARIONI, G.; AVELAR, B. R.; SUHET, J. M. M. Utilização de fonte taninífera na dieta de caprinos como alternativa de controle parasitário. Semina: Ciências Agrárias, Londrina, v. 34, n. 6, p. 2889-2902, 2013.

SON-DE FERNEX, E. V.; ALONSO-DÍAZ, M. A.; VALLES-DE LA MORA, B.; CAPETILLO-LEAL, C. M. In vitro anthelmintic of five tropical legumes on the exsheathment and motility of Haemonchus contortus infective larvae. Experimental Parasitology, New York, v. 131, n. 4, p. 413-418, 2012.

VON SAMSON-HIMMELSTJERNA, G.; COLES, G. C.; JACKSON, F. Standardization of egg hatch test for the detection of benzimidazole resistance in parasitic nematodes. Parasitology Research, Paris, v. 105, n. 3, p. 825-834, 2009. 